\title{
Measuring the Governance of Collaborative Practices for Stunting Management in Lampung, Indonesia
}

\author{
Feni Rosalia, Jeni Wulandari*, Yulianto \\ Fakultas Ilmu Sosial dan Ilmu Politik \\ Universitas Lampung \\ Lampung, Indonesia \\ *jeni.wulandari@fisip.unila.ac.id
}

\begin{abstract}
The phenomenon of stunting is one of the priority issues of national health development in the Republic of Indonesia. In Lampung Province, the government responded to this problem by establishing the Lampung Stunting Agency (LSA), which facilitates collaboration between various parties to overcome stunting. In connection with this development, this article tries to measure the governance of collaborative practices in managing stunting in Lampung Province. This article define collaboration as process in which autonomous or semiautonomous actors interact through formal and informal negotiation, jointly creating rules and structures governing their relationships and ways to act or decide on the issues that brought them together. It is a process involving shared norms and mutually beneficial interactions and consists five dimensions (governance, administration, organizational autonomy, mutuality, and norms). The researcher distributed questionnaires to 200 respondents who were selected purposively, both offline and online, who intersect with LSA. Primary data were analyzed using principal component analysis (PCA) techniques, reliability test, and confirmatory factor analysis (CFA). The results of PCA indicate that all governance indicators in this study are unidimensional and have internal consistency. The finding confirms that there is governance in the reduction of stunting in Lampung Province empirically. However, this governance still needs to be strengthened, especially in the context of formal agreements, collective decision making, and informal relations.
\end{abstract}

Keywords-collaboration, governance, stunting, health, Lampung

\section{INTRODUCTION}

Stunting is synonymous with health problems because it is related to issues of access to quality, healthy food, and nutritional literacy for pregnant women. In Indonesia, the proportion of stunted children under five years old reaches 27.67 percent or 6.3 million children. This number exceeds the maximum standard (20 percent of the total number of children under five years old in a country) set by WHO [1]. In Lampung Province, according to the 2013 Basic Health Research Survey (RISKESDAS) results, the stunting rate reached $42.6 \%$ and decreased to 27.28 percent in 2018. The Government of Lampung Province (GLP) has identified four districts as priority locations for stunting management: Lampung Tengah, Lampung Selatan, Lampung Timur, and Tanggamus [2].
To respond the stunting phenomenon, Lampung Provincial Government has formed the Lampung Stunting Agency (LSA), which is regulated by the Lampung Governor Regulation (PERGUB) Number 19 of 2019 on the Acceleration of Stunting Reduction in Lampung Province. According to this regulation, the LSA is a communication forum for strategic alliances from various stakeholders, regional work units, professional organizations, community organizations, health study programs, and non-governmental organizations (NGOs) related to accelerating the reduction in the prevalence of stunting in order to ensure the quality of gold generations in Lampung Province. This definition implicitly confirms that the LSA adopts collaborative governance in intervening of stunting in Lampung Province.

Scientifically, the issue of governance in reducing stunting has not yet received researchers' attention in Indonesia. However, it has been voiced by several researchers $[3,4]$. The results of the literature review show that previous research on stunting is more concerned with: (a) risk factors, for example, the Human Development Index [5], household welfare [6], sanitary facilities and water treatment [7], and service institutions [8], income and employment [9], infectious diseases [10], food insecurity [11], lower birth weight, six months breastfed or more, having parents who were underweight, and mothers who never attended formal education [12]; (b) protective factors, such as direct cash assistance and prosperous rice program (RASTA or Beras Sejahtera), the Program of Family Hope (PKH or Program Keluarga Harapan) [13-15], education, maternal knowledge and feeding practices [16-18], access to animal products [19]. However, there are not many studies that measure how collaborative practices in governing stunting in Indonesia.

Conceptually, the definition of collaboration that a common and accepted does not exist. This lack of clarity around collaboration is considered an obstacle to supporting and improving collaboration [20]. However, there are generic definitions that suggested for the purpose of the study: "collaboration as process in which autonomous or semiautonomous actors interact through formal and informal negotiation, jointly creating rules and structures governing their relationships and ways to act or decide on the issues that brought them together. It is a process involving shared norms 
and mutually beneficial interactions" [21]. The definition emphasizes that collaboration is a multidimensional, composed five key dimensions, structural in nature (governance and administration), social capital dimensions (mutuality and norms), and agency (organizational autonomy) [21].

One critical component of the term is "governance". Kooiman defines governance as the forms in which public or private sectors engage in problem solving, not separately but in conjunction with other actors in society [22]. This approach, therefore views governance as forms of multiorganizational actions rather than involving only state institution [23] as stated by other researchers [24,25]. For this research, we adopt Stoker's claim that governance is also about collective decision making that includes both public and private actors specifically [26]. Although public agencies may have the ultimate authority to make a decision, the goal of collaboration is typically to achieve some degrees of consensus among stakeholders [27], especially how to solve the collective action problems they face, which actions are allowed or constrained, what information need to be provided, and how cost and benefits are to be distributed [21].

\section{METHODS}

This study uses a quantitative approach. There were 200 respondents who were selected purposively and involved in the LSA. Data collection by questionnaire, both offline and online via google form.

Because there is no evidence of an existing collaboration measure in Indonesia, use of an international instrument was considered appropriate. The study adopted a research instrument developed by Thomson, Perry, and Miller [21]. This instrument was developed to address the lack of a common theory of collaboration, in order to inform practice. The instrument measures collaboration in general business, not industry-specific settings, and have been empirically tested and proven by other researchers in different research contexts [20]. For these reasons, this instrument is considered suitable for measuring collaborative practice in Indonesia context.

Respondents were asked to choose one of the five answer options available: 5 (strongly agree), 4 (agree), 3 (do not know), 2 (disagree), and 1 (strongly disagree). Data were analyzed in the following stages: (a) data entry and cleaning; (b) PCA analysis to knowing the degree of unidimensional measurement; (b) reliability test $(\alpha<0.70=$ not reliable; $\alpha>$ $0.70=$ reliable) to see the internal consistency of the measurement; (c) normality test to see data distribution; (d) CFA analysis to see the relationship between latent variables (governance) and the indicator/measured variable/manifest variable (12 statement items). The primary data analysis process was carried out using STATA 15.1 for Mac software. This research uses CFA because it commonly uses in social sciences to test whether measures of a construct or data are consistent or fit with the nature of that construct or hypothesized measurement model based on theory and/or previous analytic research.

\section{RESULTS}

\section{A. Descriptive Statistics}

The number of respondents in this study was 200 people with various socio-demographic attributes. The average age of the respondents was 36.24 years. The youngest respondent was 20 years old, and the oldest respondent was 58 years old. In other words, all respondents are of productive age. In terms of gender, this study was not too gender-biased because the difference between the number of male respondents $(54.50 \%)$ and female respondents $(45.50 \%)$ was not too large, only $9 \%$.

Respondents' domicile is quite varied because they are spread over several districts/cities in Lampung Province. Three districts account for more than 10 percent of respondents: West Tulang Bawang District (46.50\%), Pringsewu District (16.50\%), and North Lampung District (15.50\%). The rest contributed respondents below 10 percent. Although the distribution of respondents between districts/cities is not evenly distributed, the total districts/cities that are research locations are already more than half of the total districts/cities in Lampung Province. In other words, research respondents can be considered to represent Lampung Province.

In terms of ethnicity, respondents came from ethnic Javanese $(56.00 \%)$, Sundanese $(3.50 \%)$, Lampung $(30.50 \%)$, South Sumatra $(6.50 \%)$, West Sumatra $(2.50 \%)$, North Sumatra $(0.50 \%)$, and Aceh $(0.50 \%)$. The composition of respondents based on ethnicity represents the current condition of the population in Lampung Province. Meanwhile, if viewed from the respondents' education level, most respondents in this study have an education of under-graduate/equivalent $(57.50 \%)$ and high school/equivalent $(22.50 \%)$. Outside this level of education, the proportion of respondents is smaller than 10 percent.

The majority of respondents $(60.50 \%)$ came from the Ministry of Villages and Disadvantaged Areas (Kemendesa and PDT). The second position is respondents representing village government institutions. Other respondents came from district/city governments (3\%), provincial governments $(4.5 \%)$, educational institutions $(3.50 \%)$, central government/vertical agencies $(1 \%)$, community/professional organizations $(0.50 \%)$, and international non-governmental organizations (INGO) as much as $0.50 \%$.

\section{B. Principal Component Analysis}

Before being analyzed by CFA, the first step is to determine whether the twelve statements refer to one dimension of a construct/factor/latent variable or not. Based on the results, it is known that the eigenvalue score of the twelve statements reaches 3.89. All factors of loading variable score in the Factorl column are $>3$, which indicates that all items are good indicators for the governance construct (see Figure 1).

\section{Reliability test}

Based on the results, it is known that all statements' alpha $(\alpha)$ score reaches 0.7874 . Because this score is above the 
minimum score of reliability (0.70), the twelve statement items above are considered reliable or have internal consistency to explain the concept of governance (see Figure 2).

\section{Confirmatory Factor Analysis}

To obtain the final model, researchers conducted three CFA analyzes. Modification in model 1 and 2 resulted in model 3, which is the final model produced by this study.

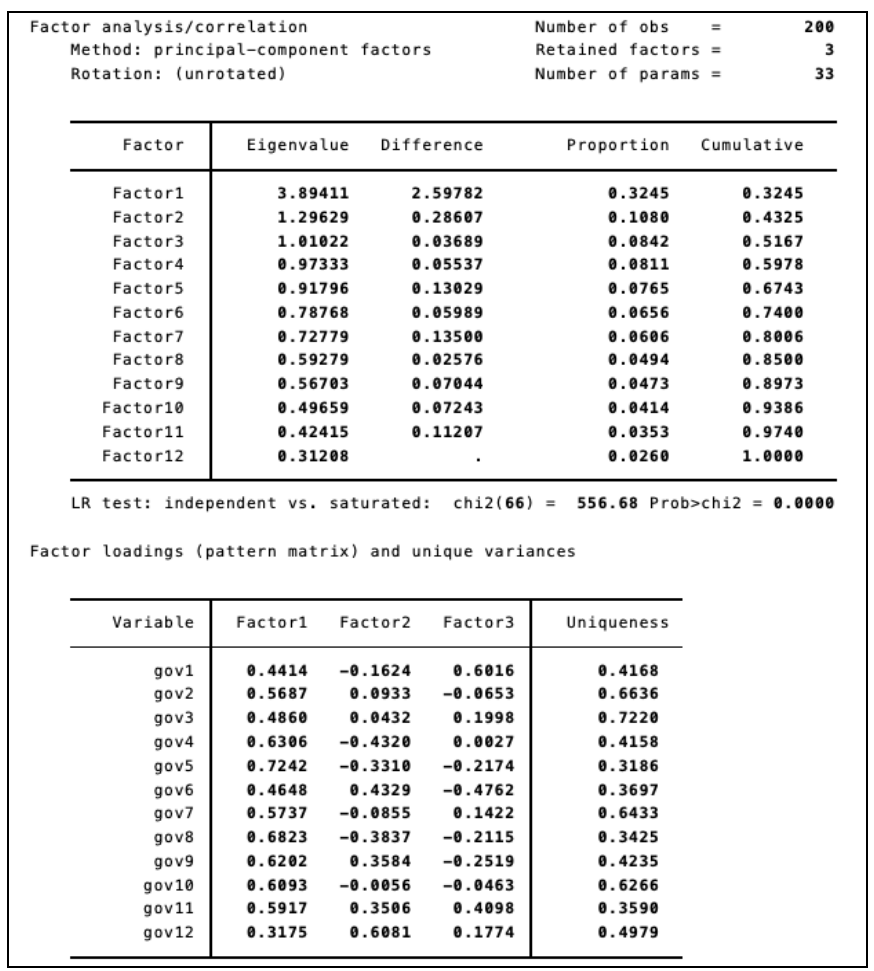

Fig. 1. The output of PCA.

\begin{tabular}{|c|c|c|c|c|c|c|c|}
\hline \multicolumn{8}{|c|}{ Test scale $=$ mean (unstandardized items) } \\
\hline Item & obs & Sign & $\begin{array}{l}\text { item-test } \\
\text { corr. }\end{array}$ & $\begin{array}{l}\text { item-rest } \\
\text { corr. }\end{array}$ & $\begin{array}{l}\text { interitem } \\
\text { cov. }\end{array}$ & alpha & Label \\
\hline gov1 & 200 & + & 0.4748 & 0.3249 & .1176875 & 0.7844 & gov1 \\
\hline gov2 & 200 & + & 0.5671 & 0.4410 & .1125171 & 0.7710 & gov2 \\
\hline gov3 & 200 & + & 0.4900 & 0.3720 & .1188433 & 0.7777 & gov3 \\
\hline gov 4 & 200 & + & 0.5634 & 0.4782 & .1180859 & 0.7702 & gov 4 \\
\hline gov5 & 200 & + & 0.6484 & 0.5572 & .110804 & 0.7607 & gov5 \\
\hline gov6 & 200 & + & 0.4949 & 0.3640 & .1174683 & 0.7789 & gov6 \\
\hline gov7 & 200 & + & 0.5586 & 0.4534 & .1155815 & 0.7703 & gov7 \\
\hline gov8 & 200 & + & 0.6075 & 0.5257 & .1157378 & 0.7661 & gov8 \\
\hline govg & 200 & + & 0.6267 & 0.5270 & .1111421 & 0.7629 & govg \\
\hline gov10 & 200 & + & 0.5925 & 0.4884 & .1132389 & 0.7668 & gov10 \\
\hline gov11 & 200 & + & 0.6455 & 0.5207 & .1056592 & 0.7620 & gov11 \\
\hline gov12 & 200 & + & 0.4439 & 0.2596 & .118931 & 0.7972 & gov12 \\
\hline Test scale & & & & & .1146414 & 0.7874 & mean (unstandardized items) \\
\hline
\end{tabular}

Fig. 2. The output of reliability test.

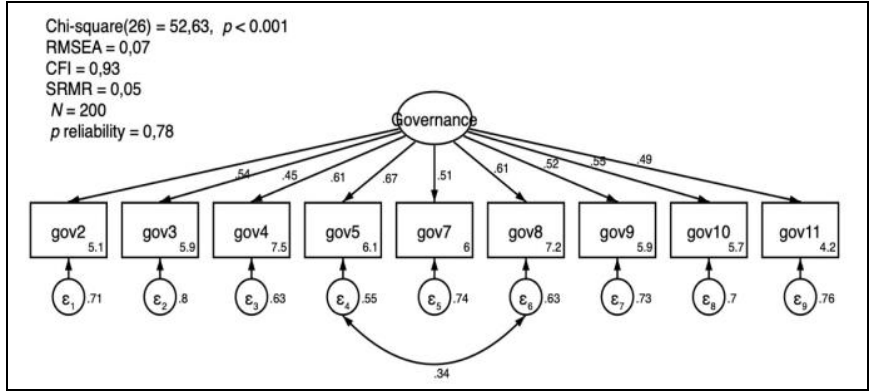

Fig. 3. The visualization of the final model.

The final model is not perfect (does not reflect empirical data in the field), $X^{2}(26), \mathrm{p}<0.001$, because many other indicators have not been included in the model. However, the model is viable and proper, because it passes the goodness-offit test. This is indicated by the ideal RMSEA (0.072), CFI (0.933), and SRMR (0.053) scores (RMSEA: 0.05 - 0.08), also ideal (CFI: 0.95), and ideal (SRMR): <0.08) (see Figure 3).

\section{DiscusSION}

The CFA analysis results confirm the existence of empirical facts about governance practices in reducing stunting in Lampung Province. Of the nine indicators, the gov5 indicator (Partner organizations (including your organization) formally evaluate the success of the collaboration) has the highest loading factor/path loading (See appendix 1), which is 0.67 . It indicates a policy learning process between the collaborating actors. However, to what extent this policy learning process has an impact on improving governance as a whole still needs to be further explored.

The gov5 indicator correlates with the gov8 indicator (Your organization knows the reasons why the partner organization is part of the collaboration). The gov5 and gov8 indicators' total measurement errors contributed as much as 0.34 percent significantly to the overall model. The factor loading indicator gov8 is also convincing (0.61), taking the second place alongside the gov4 indicator (Partner organizations take your organization's views seriously when decisions about collaboration are made). The gov8 indicator means an exchange of ideas, discussion, dialogue in the process of overcoming stunting. Meanwhile, the gov4 indicator indicates a collective decision-making process characterized by negotiation, compromise, and sharing perspectives.

Indicator of gov2 (Your organization relies on standard operating procedures (such as rules, policies, forms) established by partner organizations to coordinate the activities of each other in collaboration), gov7 (Your organization knows what resources (such as money, time, expertise) the partner organization brings to the collaboration), gov9 (Your organization brainstorms with partner organizations to develop solutions to mission-related problems encountered in the collaborative process), and gov10 (Your organization is involved in implementing specific solutions to mission-related problems facing collaboration) has a factor loading of 0.54 , 
$0.51,0.52$, and 0.55 , respectively. It means that the collaborative process in tackling stunting in Lampung Province is formal and uses modern administration (gov2), triggers an exchange of resources (gov7), an exchange of perspectives, and policy learning (gov9), and collective action (gov10).

There are only two indicators that have a factor loading of 0.4: gov3/ Your organization participates in a board/steering committee/agency specially created to make decisions about collaboration (0.45); and gov11/ Partner organizations (including your organization) rely on the mission statement for collaboration that is different from the respective partner organizations' mission statements (0.49). The gov3 indicator confirms the existence of a governance structure in overcoming stunting in Lampung Province. In contrast, the gov11 indicator shows a shared mission and sharing agenda-setting in the collaborative process. So, although each actor has their agenda, they can agree on issues that become common agendas that require collective action.

Of the twelve indicators of governance, three indicators have a factor loading of < 0.4: gov1 (Your organization relies on a formal agreement that describes the relationship with partner organizations), gov6 (All partner organizations (including your organization) must agree before decisions about collaborative goals and activities are made), and gov12 (Your organization relies on informal personal relationships with partner organizations when making decisions about collaboration). It indicates a weak point of the governance in tackling stunting in Lampung Province. Formal agreements (gov1), mutual consent (gov6), and informal relations (gov12) are still very minimal in tackling stunting in Lampung Province. These three things can be a starting point for strengthening governance in Lampung Province, especially in stunting.

Although there is already a collective decision-making process that prioritizes negotiation, compromise, and sharing perspectives (gov5), this process does not always guarantee that the final decision regarding collaboration gets mutual agreement (gov6). Some actors may take decisions unilaterally because of certain considerations that may not be agreed by all parties. This analysis strengthens theorists' arguments about the influence of governance structures, political-economic interests, authority structures, and motivations that affect the collaboration process [28,29]. Consequently, today's collective action (gov10), mission and agenda-setting (gov11), and participation in governance structures (gov3) are artificial, for example, a collaborative process that is thought to emerge topdown.

This study's results strengthen the instrument developed by Thomson, Perry, and Miller [21] as a good measuring tool for analyzing governance phenomena in the context of collaboration. The existence of a policy learning process (gov5), dialogical communication (gov8), negotiation, and compromise (gov4) strengthens previous theoretical arguments about mutual adjustment and shared perspectives between actors in the collaboration process [30]. The exchange of resources (gov7) that occurs between actors in the prevention of stunting in Lampung Province also strengthens the results of previous studies [29,31]. The lack of informal relationships (gov12) reinforces the argument about the importance of building effective personal relationships [32].

Based on the above findings, this study recommends that the parties, especially the Provincial Government of Lampung, are involved in the management of stunting reduction to strengthen collaborative practices into certain legal agreements. LSA institutions need to be strengthened with education and training. LSA is also advised to immediately prepare a road map and document best practices as part of efforts to manage knowledge (knowledge management) to prevent stunting. Informal meetings between actors must be held frequently to improve the quality of informal relations between actors.

\section{CONCLUSION}

Collaborative practice in reducing stunting in Lampung Province requires strengthening in the aspects of formal agreements, collective agreements, and informal relations. Therefore, there are two main agendas that need to be prioritized; First, related to the governance structure, there needs to be clarity on the position and role of the district/city government in LSA. Second, the need for community participation in educating nutritional issues, and promoting stunting as a common problem that must be intervened with the voluntarism mechanism. The need to package a variety of nutrition education messages (text, images, audio, and audiovisual) that are most readily accepted by the community.

\section{ACKNOWLEDGMENT}

This research was fully funded by the Rector of the University of Lampung through the Professorship Grant scheme in 2020.

\section{REFERENCES}

[1] M. Umakaapa, Strategi 2020 melawan stunting, www.detik.com, 2020 [Online]. Available: https://news.detik.com/kolom/d-4858547/strategi2020-melawan-stunting. [Accessed: 20-Aug-2020].

[2] A. Atika, Empat kabupaten kasus tertinggi stunting, www.lampost.co, Bandar Lampung, Lampung, Indonesia, 2019.

[3] M. Hossain, N. Choudhury, K.A.B. Abdullah, P. Mondal, A.A. Jackson, J. Walson and T. Ahmed, "Evidence-based approaches to childhood stunting in low and middle income countries: A systematic review," Arch. Dis. Child., vol. 102, no. 10, pp. 903-909, 2017.

[4] J. Jap, S. Sumarmi, and N.A. Damayanti, "Importance of collaborative intervention of preconception nutrition in suppressing the stunting case in East Nusa Tenggara, Indonesia,” Indian J. Public Heal. Res. Dev., vol. 10, no. 9, pp. 698-702, 2019.

[5] S. Muljati, A. Triwinarto, and B. Budiman, "Determinan stunting pada anak usia 2-3 tahun di tingkat provinsi," Penelit. Gizi dan Makanan, vol. 34, no. 1, pp. 50-62, 2011.

[6] C.R. Titaley, I. Ariawan, D. Hapsari, A. Muasyaroh, and M.J. Dibley, "Determinants of the stunting of children under two years old in Indonesia: A multilevel analysis of the 2013 Indonesia basic health survey," Nutrients, vol. 11, no. 5, p. 1106, May 2019. 
[7] H. Torlesse, A.A. Cronin, S.K. Sebayang, and R. Nandy, "Determinants of stunting in Indonesian children: Evidence from a cross-sectional survey indicate a prominent role for the water, sanitation and hygiene sector in stunting reduction," BMC Public Health, vol. 16, no. 1, pp. 1$11,2016$.

[8] M.F. Rizal and E. van Doorslaer, "Explaining the fall of socioeconomic inequality in childhood stunting in Indonesia," SSM - Popul. Heal., vol. 9, p. 100469, 2019.

[9] Ramli, K.E. Agho, K.J. Inder, S.J. Bowe, J. Jacobs, and M.J. Dibley, "Prevalence and risk factors for stunting and severe stunting among under-fives in North Maluku province of Indonesia," BMC Pediatr., vol. 9, no. 1, p. 64, Dec. 2009.

[10] D. Arini, Nursalam, Mahmudah, and I. Faradilah, "The incidence of stunting, the frequency/duration of diarrhea and acute respiratory infection in toddlers," J. Public health Res., vol. 9, no. 1816, pp. 117120, Jul. 2020.

[11] T. Mahmudiono, T. Nindya, D. Andrias, H. Megatsari, and R. Rosenkranz, "Household food insecurity as a predictor of stunted children and overweight/obese mothers (SCOWT) in urban Indonesia," Nutrients, vol. 10, no. 5, p. 535, Apr. 2018.

[12] C.N. Rachmi, K.E. Agho, M. Li, and L.A. Baur, "Stunting, underweight and overweight in children aged 2.0-4.9 years in Indonesia: Prevalence trends and associated risk factors," PLoS One, vol. 11, no. 5, p. e0154756, May 2016.

[13] M. Aries, H. Hardinsyah, and H. Tuhiman, "Determinan gizi kurang dan stunting anak umur 0-36 bulan berdasarkan data program keluarga harapan (PKH) 2007," J. Gizi dan Pangan, vol. 7, no. 1, pp. 19-26, Mar. 2012 .

[14] D. Kusuma, M. McConnell, P. Berman, and J. Cohen, "The impact of household and community cash transfers on children's food consumption in Indonesia," Prev. Med. (Baltim)., vol. 100, pp. 152-158, 2017.

[15] T. A. Ahmad, N.K.T. Martuti, S.B. Nugraha, A. Amidi, W. Aksin, and B.N. Sidiq, "Kajian kelayakan penerima manfaat (Gakin PKH) terhadap program bantuan pemerintah di kota Semarang," J. Riptek, vol. 13, no. 2, pp. 114-123, 2019.

[16] S.M. Damanik, D. Wanda, and H. Hayati, "Feeding practices for toddlers with stunting in Jakarta: A case study," Pediatr. Rep., vol. 12(s1), no. 8695, pp. 18-22, Jun. 2020.

[17] P.D. Novitasari, and D. Wanda, "Maternal feeding practice and its relationship with stunting in children," Pediatr. Rep., vol. 12(s1), no. 8698, pp. 30-33, Jun. 2020.

[18] C. Starkweather, A. Guarino, N. Bennion, M. Cottam, J. McGhie, K.A Dearden and O. Santika "An interpersonal nutrition campaign and maternal knowledge and childhood feeding practices: a case study from mothers in rural Indonesia," Arch. Public Heal., vol. 78, no. 62, pp. 1-6, Dec. 2020.

[19] M. Sekiyama, H.W. Jiang, B. Gunawan, L. Dewanti, R. Honda, H. Shimizu-Furusawa, O.S. Abdoellah and C. Watanabe, "Double burden of malnutrition in rural West Java: Household-level analysis for fatherchild and mother-Child pairs and the association with dietary intake," Nutrients, vol. 7, no. 10, pp. 8376-8391, Oct. 2015.

[20] D. Roberts, R. Van Wyck, and N. Dhanpat, "Validation of the Thomson, Perry, and Miller (2007) collaboration instrument in the South African context," SA Journal of Human Resource Management, vol.15, no. 0, pp. 1-11, 2017.

[21] A.M. Thomson, J.L. Perry, and T.K. Miller, "Conceptualizing and measuring collaboration,” J. Public Adm. Res. Theory, vol. 19, no. 1, pp. 23-56, Nov. 2007.

[22] J. Kooiman, Modern Governance: New-Government Society Relations, London: Sage, 1993.

[23] M. Asaduzzaman, and P. Virtanen, "Governance theories and models, In A. Farazman (eds), Global Encyclopedia of Public Administration, Public Policy, and Governance, Springer, 2016.

[24] J. Graham, B. Amos, and T. Plumptre, "Governance principles for protected areas in the 21 st century", Ontario, Canada: Institute on Governance, 2003.

[25] P. Landell-Mills, and I. Serageldin, "Governance and the externa factor", The World Bank Economic Review, vol. 5, pp. 303-320, 1991.

[26] G. Stoker, "Governance as theory: Five propositions, International Social Science Journal, vo. 50, pp. 17-28, 1998.

[27] C. Ansell, and A. Gash, "Collaborative governance in theory and practice", Journal of Public Administration Research and Theory, vol. 18 , pp. 543-571, 2007.

[28] L.E. Lynn Jr., C.J. Heinrich, and C.J. Hill, "Studying governance and public management: Challenges and prospects," J. Public Adm. Res. Theory J-PART, vol. 10, no. 2, pp. 233-261, 2000.

[29] E. Ostrom, "Beyond markets and states: Polycentric governance of complex economic systems," Am. Econ. Rev., vol. 100, no. 3, pp. $641-$ $672,2010$.

[30] I. Bode and O. Firbank, "Barriers to co-governance: Examining the 'chemistry' of home-care networks in Germany, England, and Quebec,' Policy Stud. J., vol. 37, no. 2, pp. 325-351, 2009.

[31] I. Blanco, V. Lowndes, and L. Pratchett, "Policy networks and governance networks: Towards greater conceptual clarity," Polit. Stud. Rev., vol. 9, no. 3, pp. 297-308, 2011.

[32] R.H. Dehoog, "Collaborations and partnerships across sectors: Preparing the next generation for governance," J. Public Aff. Educ., vol. 21, no. 3, pp. 401-416, 2015. 